\title{
POŠTA
}

TELEKOMUNIKÁCIE A

ELEKTRONICKY OBCHOD

\section{AKCEPTÁCIA INTERNETOVEJ REKLAMY Z POHLADU VYBRANÝCH SEGMENTOV}

\author{
Radovan Madleňák*
}

\section{1. ÚVOD DO PROBLEMATIKY}

Mnoho firiem pre správnu vol'bu trhových segmentov využíva cielený marketing, ktorý zahrňuje identifikáciu hlavných trhových segmentov, vol'bu jedného alebo niekolkých prítažlivých segmentov, vývoj vhodného produktu a marketingových programov odpovedajúcich špecifickým zákazníckym potrebám a prianí na danom trhovom segmente. Pri cielenom marketingu namiesto širokého výrobného a marketingového programu firmy sa kladie dôraz na prispôsobenie produktu a marketingu požiadavkám cielových zákazníkov.

Tabul'ka č. 1 Hlavné segmentačné premenné

\begin{tabular}{|llll|}
\hline Geografické & Demografické & Psychografické & Správanie sa \\
\hline Oblast' & Vek & Životný štýl & Príležitost' \\
Počet obyvatel'ov & Vel'kost' rodiny & Osobnost' & Úžitok \\
Charakter oblasti & Životný cyklus rodiny & & Užívatel'ský status \\
& Mesačný príjem & & Stupeň používania \\
& Povolanie & & Status vernosti \\
& Vzdelanie & & Stupeň pripravenosti \\
& Náboženstvo & Postoj k výrobku \\
& Národnost' & \\
& Spoločenská vrstva & & \\
\hline
\end{tabular}

Jednou zhlavných segmentačných premenných je segmentácia na základe demografických premenných. Pri demografickej segmentácii je trh rozčlenený podla demografických premenných, ako je vek, vel'kost' rodiny, mesačný príjem, pohlavie, atd'. Tieto kritéria sú oblúbeným základom pre rozlišovanie skupín zákazníkov. Po prvé preto, že potreby, priania a preferencie zákazníkov sú silne spojené s demografickými premennými a po druhé, že demografické premenné sú l’ahko meratel'né. Medzi zaujímavé pohlady na demografické zloženie trhu je nazeranie na trh z pohl’adu generácie. Základnou myšlienkou tohto prístupu je, že každá generácia bola hlboko ovplyvňovaná prostredím, v ktorom vyrastala.

\section{REALIZÁCIA VÝSKUMU}

Analýza akceptácie internetovej reklamy bola vykonávaná anonymnou dotazníkovou metódou. Dopytovanie bolo realizované jednorázovo v obdobiach marec 2008 a marec 2010. Dotazník bol aplikovaný na náhodne zvolenú skupinu respondentov rôznych vekových

\footnotetext{
* doc. Ing. Radovan Madleňák, PhD., Katedra spojov, Fakulta prevádzky a ekonomiky dopravy a spojov, Žilinská univerzita v Žiline, Univerzitná 1, 01026 Žilina, Slovenská republika tel.: +421/41/513 3124, e-mail: radovan.madlenak@fpedas.uniza.sk
} 
kategórií a bol šírený elektronickou formou. Počet respondentov, ktorí sa v oboch rokoch zúčastnilo dopytovania bolo 250 a bolo im položených 18 otázok, pričom na niektoré z nich bola možnost' jednej odpovede a na niektoré možnost' viacerých odpovedí.

\section{VÝSLEDKY MARKETINGOVÉHO VÝSKUMU}

Výsledky dopytovania boli porovnávané v jednotlivých rokoch na základe zvolenia si demografickej segmentačnej premennej - vek (generácia) respondentov.

\section{A. Segment mladá generácia - veková kategória 19 až 24 rokov}

V oblasti akceptácie internetovej reklamy sa názor vekovej kategórie 19 - 24 rokov nezmenil a v roku 2008 a aj v roku 2010 označili za najprijatel'nejšie typy internetovej reklamy tieto druhy: banner, vodotlač, inzertné linky. V oblasti bannerovej reklamy v roku 2010 nastal mierny nárast oproti roku 2008. Respondenti vo veku $19-24$ rokov označili ako prijatel'ný typ aj kontextovú reklamu, ktorá bola pridaná do dotazníka uskutočňovaného $\mathrm{v}$ roku 2010.

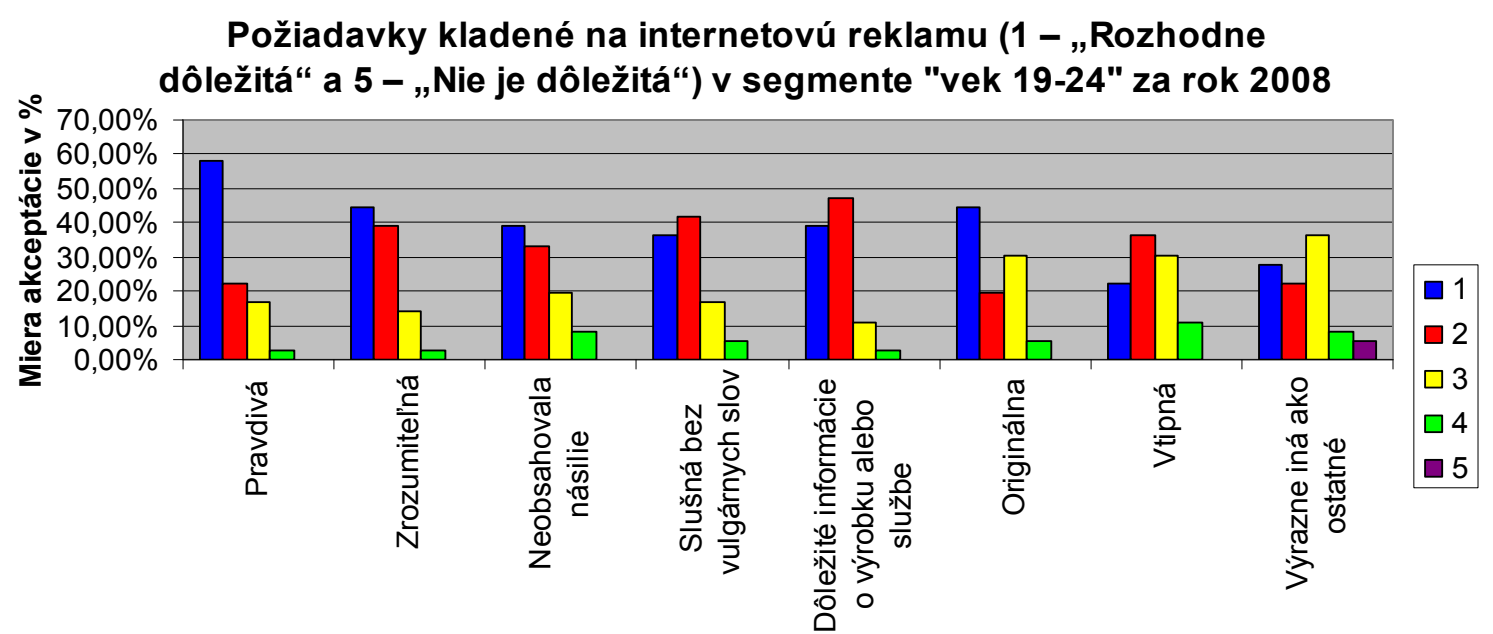

Obrázok 1 Požiadavky na internetovú reklamu na segmente 19 - 24 rokov za rok 2008

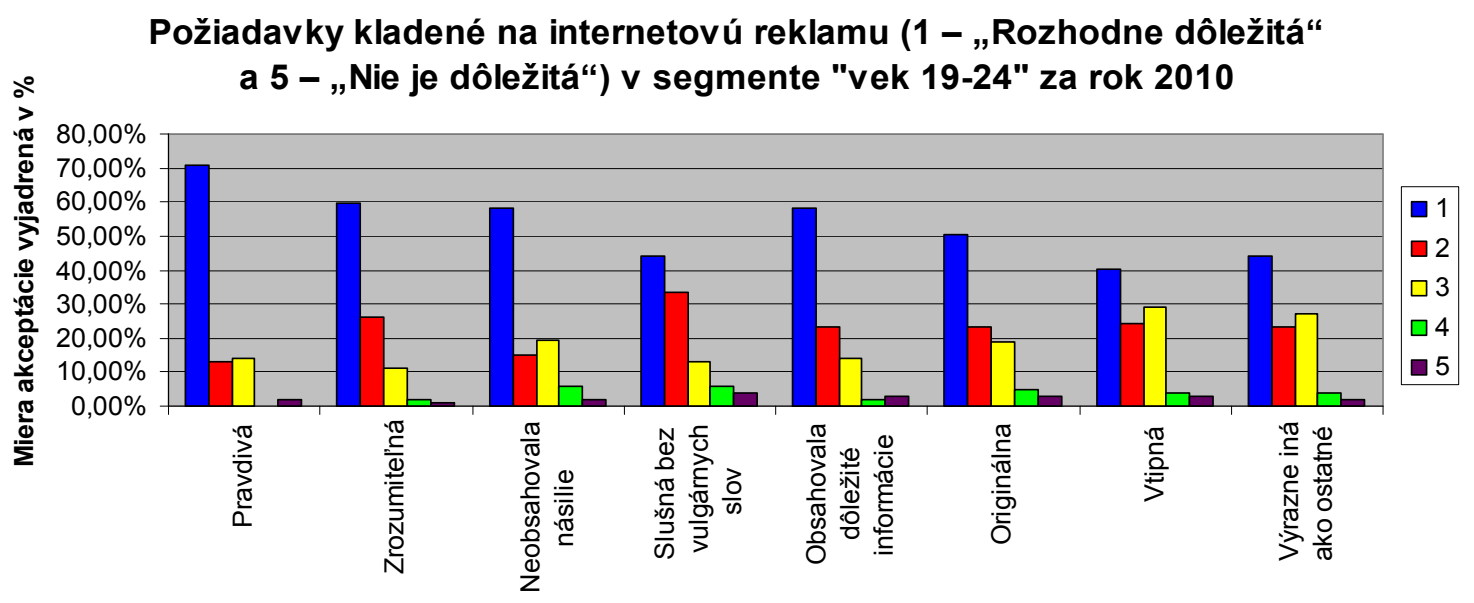

Obrázok 2 Požiadavky na internetovú reklamu na segmente 19 - 24 rokov za rok 2010

Na vyššie uvedených obrázkoch (obrázok č. 1 a č. 2) sú znázornené požiadavky na internetovú reklamu respondentov vo vekovej kategórii 19 - 24 rokov. Pri porovnávaní 
výsledkov prieskumu za roky 2008 a 2010 je vidiet' badatel'né rozdiely v reakciách na konkrétne postoje k internetovej reklame. V roku 2008 považuje pravdivost' za rozhodne dôležitú 58,33 \% respondentov vo veku $19-24$ rokov a v roku 2010 nastalo mierne zvýšenie na $71,03 \%$ týchto respondentov. Zrozumitel'nost' označilo za rozhodne dôležitú 44,44 \% respondentov tohto segmentu v roku 2008 a 59,81 \% v roku 2010. Ďalej l'udia vo veku 19 24 rokov, ktorí sa zúčastnili dopytovania považujú za dôležité aj požiadavky vtipnosti a toho aby reklama obsahovala dôležité informácie o ponúkaných výrobkoch a službách. $\mathrm{Na}$ tieto požiadavky reagovalo a zároveň ich považovalo za rozhodne dôležité o $20 \%$ respondentov viac ako v roku 2010. Respondenti vekovej kategórie 19 - 24 rokov trávia značnú čast' svojho vol'ného času na rôznych sociálnych siet’ach, kde sa často stretávajú s internetovou reklamou. Preto aj odpovede k otázke ohl'adom požiadaviek na túto reklamu môžu byt' založené na skúsenostiach s reklamou na rôznych sociálnych siet'ach. Pokial' sa respondenti $\mathrm{z}$ tohto segmentu stretli s nepravdivou a nezrozumitel'nou reklamou na týchto webových stránkach, tak v dotazníku označili požiadavku zrozumitel’nosti a pravdivosti ako rozhodne dôležitú.

Čo sa týka všeobecných postojov, tak u vekovej kategórie 19 - 24 rokov nedošlo k rozdielnym odpovediam za roky 2008 a 2010. Mladí l'udia súhlasili s danými postojmi rovnako v oboch rokoch.

\section{B. Segment stredná generácia - veková kategória 25 až 34 rokov}

$\mathrm{Na}$ obrázkoch č.3 a č.4 sú znázornené najprijatel'nejšie typy internetovej reklamy v segmente vekovej kategórie 25 - 34 rokov za roky 2008 a 2010 . Z obrázkov vyplýva, že u respondentov tohto segmentu $\mathrm{v}$ istej miere došlo $\mathrm{k}$ malej zmene $\mathrm{v}$ akceptácii reklamy, síce v roku 2010 sú akceptované tie isté typy internetovej reklamy ako v roku 2008 (banner, vodotlač, reklamné emaily a inzertné linky), ale v roku 2010 nie je percentuálne zastúpenie daných typov internetovej reklamy v takej miere ako v roku 2008. Výsledky výskumu v roku 2010 v tomto segmente poukazujú na to, že zadávatelia reklamy aj vplyvom hospodárskej krízy neadresovali také množstvo internetovej reklamy ako v roku 2008, namiesto toho sa zamerali na agresívnejšie typy interventovej reklamy(pop up okno, comic cursor, stick advertising). To mohlo spôsobit', že respondenti sa skôr vyjadrovali k neprijatel'nosti agresívnych typov ako ku akceptovatel'nosti neagresívnej reklamy.

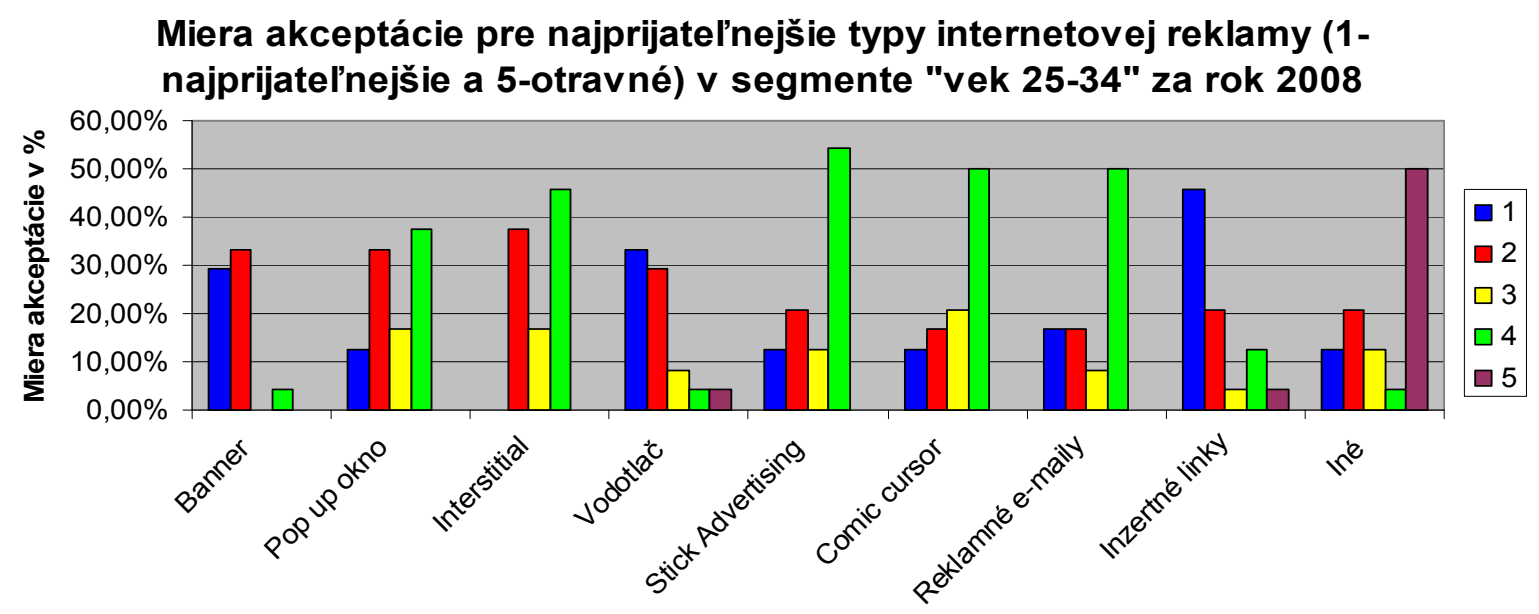

Obrázok 3 Miera akceptácie pre najprijatel’nejšie typy internetovej reklamy na segmente 25 34 rokov za rok 2008 


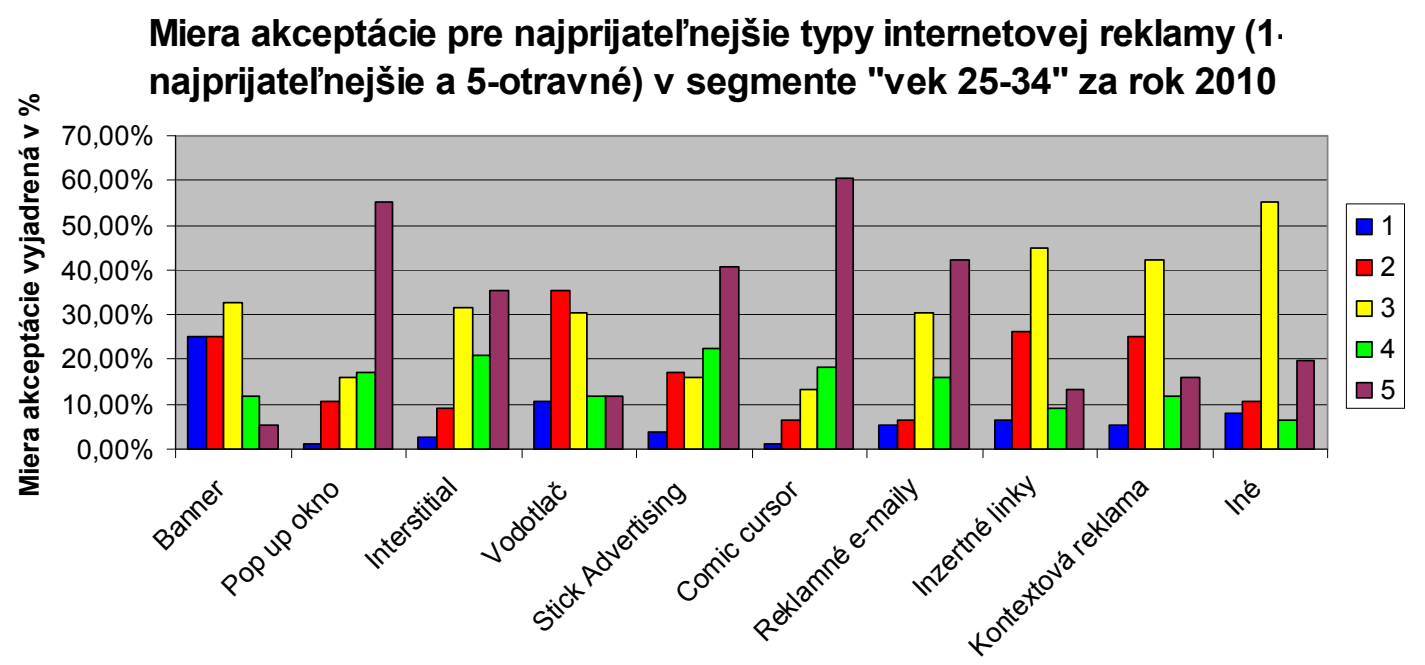

Obrázok 4 Miera akceptácie pre najprijatel’nejšie typy internetovej reklamy na segmente 25 34 rokov za rok 2008

Pravdivost', zrozumitel'nost', aby neobsahovala násilie, slušná bez vulgárnych slov originálna, vtipná a aby obsahovala dôležité informácie o výrobku tieto požiadavky na internetovú reklamu označil respondenti vekovej kategórie 25 - 34 rokov za rozhodne dôležité v roku 2008 ale aj v roku 2010.

Všeobecné postoje $k$ internetovej reklame $(1$ - „Úplne súhlasím

“ a 4 - „Úplne nesúhlasím") v segmente "vek 25-34" za rok 2010

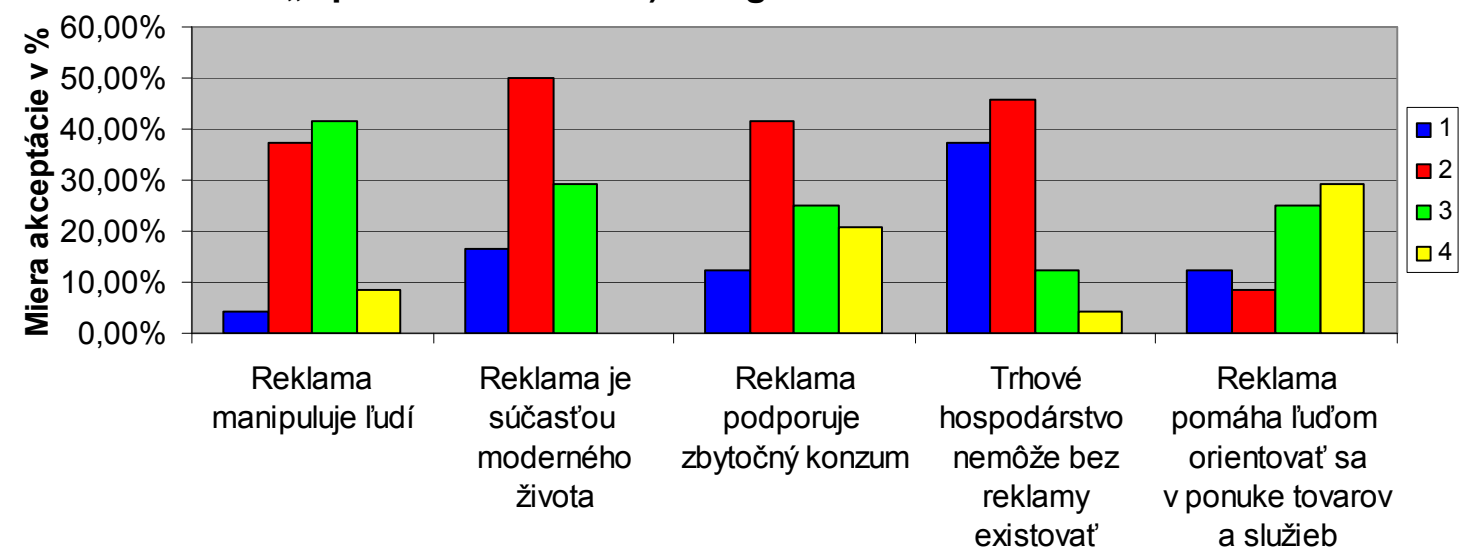

Obrázok 5 V̌eobecné postoje k internetovej reklame na segmente 25 - 34 rokov za rok 2008

Na obrázkoch č.5 a č.6 je môžé vidiet' vel'ké rozdiely vo všeobecných postojoch za rok $2008 \mathrm{~s}$ porovnaním s rokom 2010 hlavne v úplnom súhlase pre daný postoj. Najviac viditel'né to je pri postoji reklama manipuluje l'udí, s ktorým úplne súhlasí 4,17 \% respondentov vo veku 25 - 34 rokov zúčastnených dopytovania v roku 2008 a v roku 2010 úplne súhlasilo až $36,84 \%$ respondentov tohto segmentu. Tak tiež vel'ký percentuálny nárast vidiet' v postoji reklama je súčast'ou moderného života. Tieto vel'ké výkyvy v postojoch mohli byt' spôsobené bud' zmenou vnímania internetovej reklamy ako celku alebo odlišnou štruktúrou respondentov vyplňujúcich dotazník v roku 2008 a v roku 2010. 


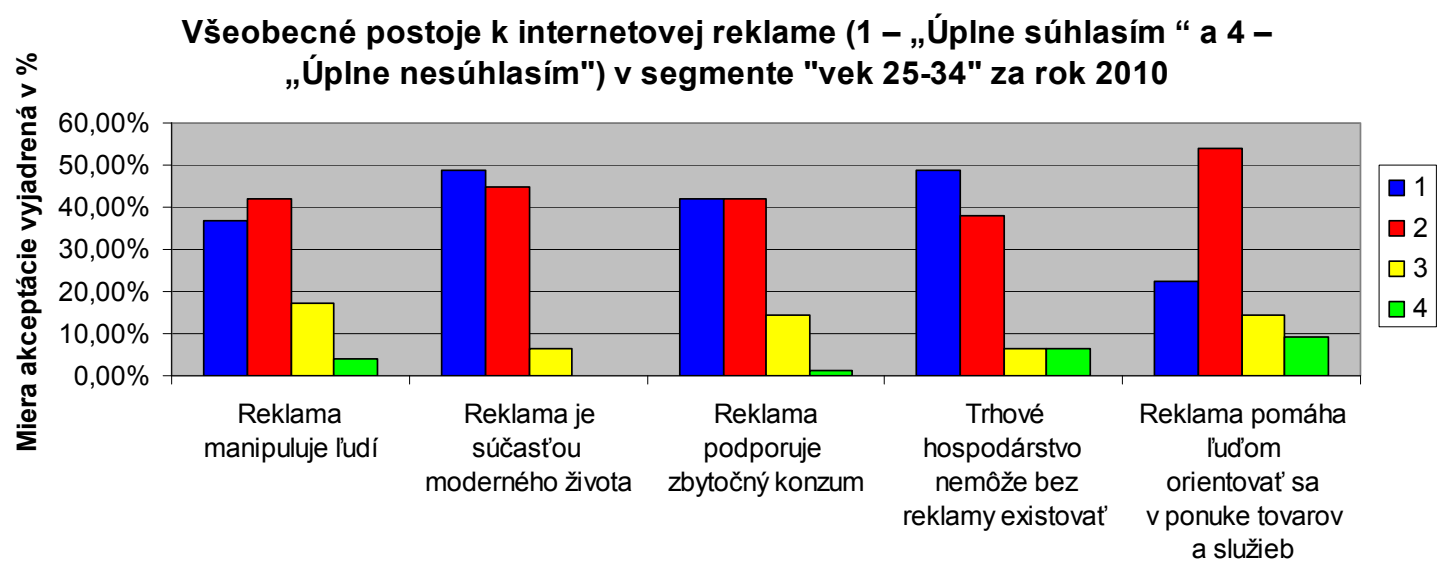

Obrázok 6 V̌̌eobecné postoje k internetovej reklame na segmente 25 - 34 rokov za rok 2010

\section{Segment staršia generácia - veková kategória 35 - 54 rokov}

Oblast' akceptácie najprijatel'nejších typov internetovej reklamy v segmente veková kategória 35 - 54 rokov nezaznamenal výrazne zmeny za roky 2008 a 2010. Respondenti z tejto vekovej kategórie aj v roku 2008 aj v roku 2010 označili za prijatel'né tieto typy internetovej reklamy: banner, reklamné e-maily, inzertné linky.

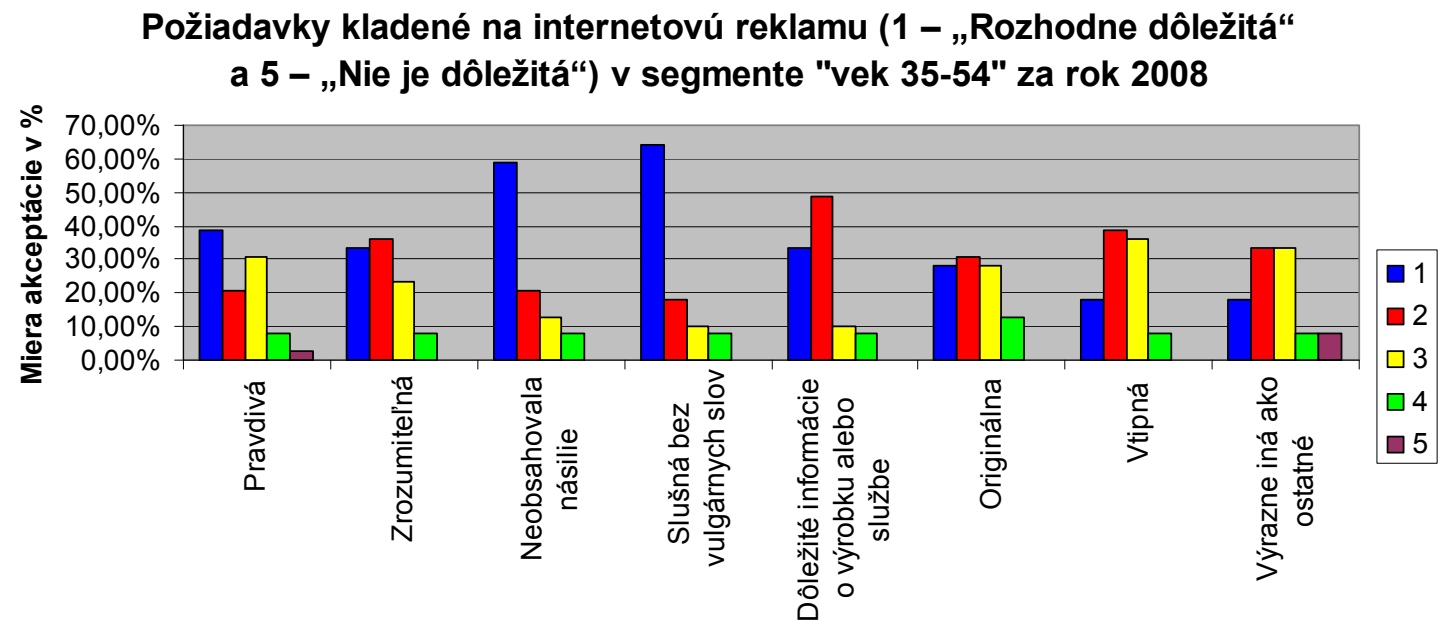

Obrázok 7 Požiadavky k internetovej reklame na segmente 35 - 54 rokov za rok 2008

Z obrázkov č.7 a č.8 je vidiet' evidentný rozdiel v požiadavkách kladených na internetovú reklamu u respondentov vo veku 35 - 54 rokov. V roku 2008 mali vysoké percentuálne zastúpenie požiadavky aby reklama neobsahovala násilie $(58,97 \%)$ a aby bola reklama slušná bez vulgárnych slov $(64,10 \%)$. V roku 2010 respondenti z tohto segmentu považovali za rozhodne dôležité (výrazným percentuálnym podielom) všetky požiadavky kladené na internetovú reklamu. Pravdivost', zrozumitel'nost', obsahovost' dôležitých informácií o výrobkoch a službách, bez vulgárnych slov a násilia tieto požiadavky akceptovalo viac ako $70 \%$ respondentov z tohto segmentu. Jedným z dôvodov môže byt' aj opatrné nákupne rozhodovanie počas, ale aj po skončení hospodárskej krízy. Z toho vyplýva, že tento segment priradil pravdivosti, dôležitosti, slušnosti a obsahovosti dôležitých informácii vel'kú mieru dôležitosti. 


\section{Požiadavky kladené na internetovú reklamu (1 - „Rozhodne dôležitá“ a 5 - „Nie je dôležitá“) v segmente "vek 35-54" za rok 2010}

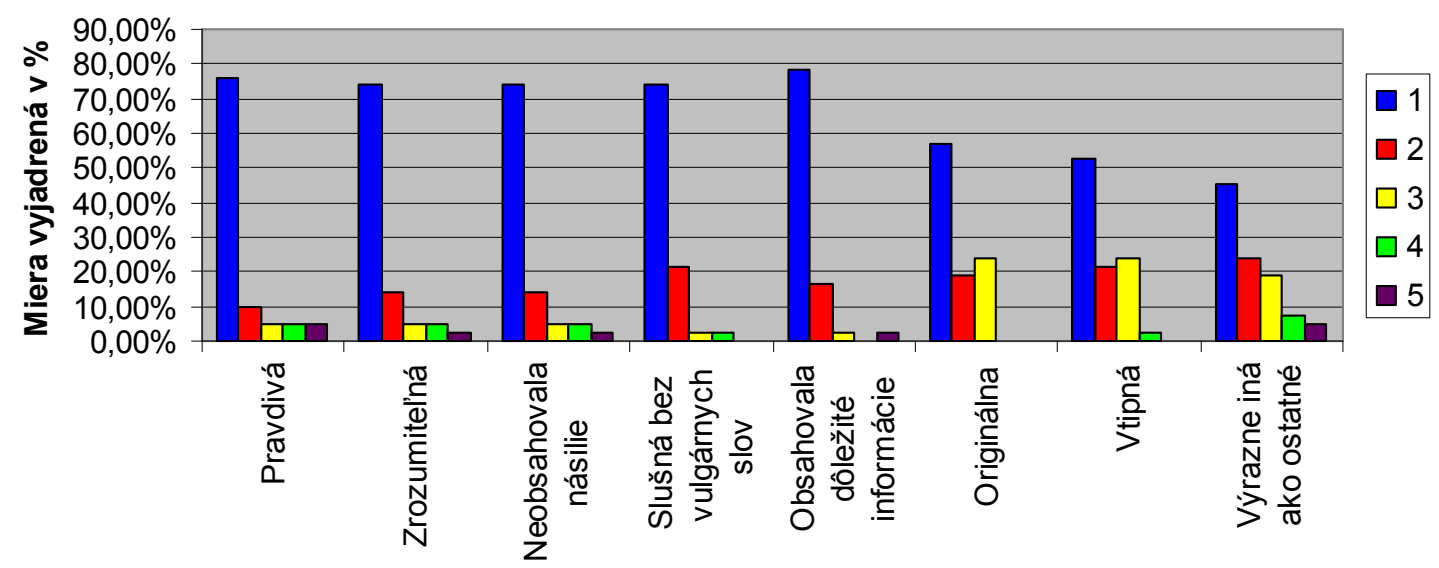

Obrázok 8 Požiadavky k internetovej reklame na segmente 35 - 54 rokov za rok 2010

Z obrázkov č.9 a č.10 môžeme vyčítat', že k všeobecným postojom k internetovej reklame sa vyjadrili respondenti s väčším súhlasom v roku 2010 než v roku 2008. Reklama manipuluje l'udí, $\mathrm{k}$ tomuto postoju vyjadrilo úplný súhlas takmer $18 \%$ oslovených $\mathrm{v}$ tomto segmente v roku 2008 a 45,24 \% respondentov v roku 2010. Takmer $13 \%$ oslovených v roku 2008 úplne súhlasí s postojom, že reklama je súčast'ou moderného života, ale v roku 2010 to bolo až 38,10 \% respondentov vo veku 35 - 54 rokov. Takmer $17 \%$ rozdiel je vidiet' aj v postoji, že trhové hospodárstvo nemôže bez reklamy existovat'.

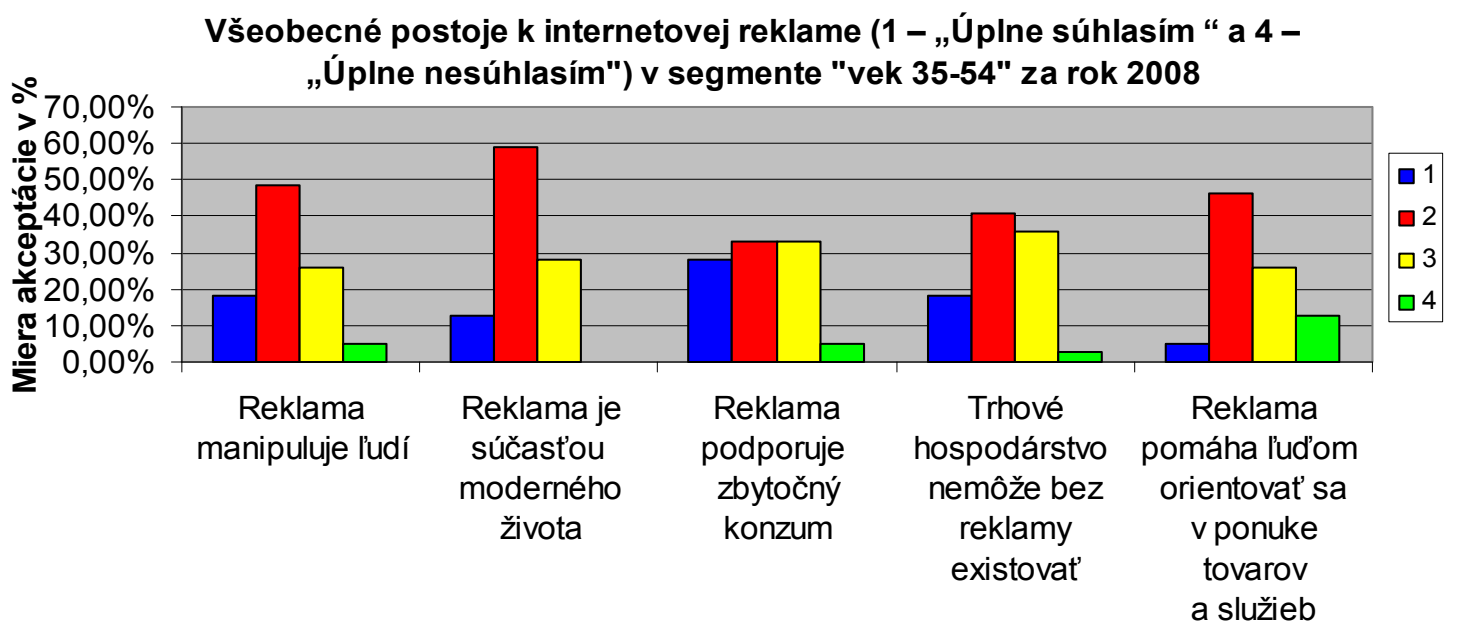

Obrázok 9 V̌eobecné postoje k internetovej reklame na segmente 35 - 54 rokov za rok 2008 


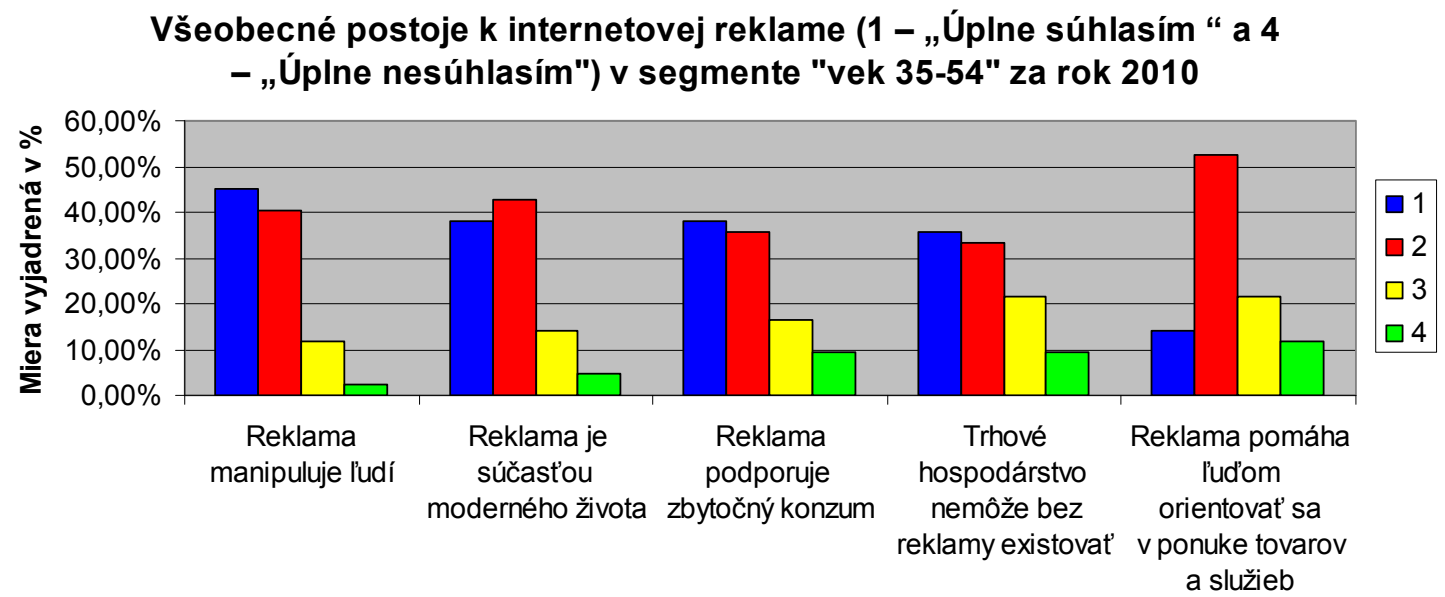

Obrázok 10 V̌̌eobecné postoje k internetovej reklame na segmente 35 - 54 rokov za rok 2008

\section{ZÁVER}

$\mathrm{Na}$ základe realizovaného dopytovania a následnej analýzy a komparácie výsledkov z rokov 2008 a 2010 je možné stanovit' nasledujúce odporúčania ako čo najlepšie oslovit' príslušné generačné skupiny a úspešne následne využit' jednotlivé druhy internetovej reklamy.

\section{A. Segment veková kategória $19-24$ rokov}

Najlepšou cestou ako oslovit' vekovú kategóriu 19 - 24 rokov je prostredníctvom vtipnej mierne agresívnej internetovej reklamy, ktorá je zrozumitel’ná a originálna. Ako typ internetovej reklamy by bolo vhodné využit' banner alebo kontextovú reklamu v istej miere aj inzertné linky. Naopak pokles v roku 2010 oproti roku 2008 bol zaznamenaný v reklamných emailoch. Táto veková kategória by mala mat' možnost' upravit' reklamu podl'a svojich predstáv, čím by zadávatel'ovi internetovej reklamy pribudli nové možnosti a nápady ako túto reklamu zdokonalit', aby bola čo najúčinnejšia pre danú vekovú kategóriu. Vel'mi dôležitým prvkom je aj zacielenie internetovej reklamy aj prostredníctvom sociálnych sieti, ktorých využívanie je v poslednej dobe vel'mi oblúbené.

\section{B. Segment veková kategória $25-34$ rokov}

Z porovnávania výskumov z rokov 2008 a 2010 je vidiet' menšiu mieru akceptovatel'nosti všetkých druhov interventovej reklamy u vekovej kategórie 25 - 34 rokov. To znamená, že v tomto segmente nie je podstatné akým typom internetovej reklamy zadávatel' tejto reklamy pôsobí, ale to, akú reakciu to u potenciálnych zákazníkov vyvolá. Významnou zložkou tejto reklamy je určite oslovenie l'udí tejto vekovej kategórie pravdivou a zrozumitel'nou reklamou a samozrejme obsah dôležitých informácii o ponúkaných výrobkoch a službách je pozitívom.

\section{Segment veková kategória 35 - 54 rokov}

Banner a kontextovú reklamu by bolo vhodné využit' ako typy internetovej reklamy cielenej na vekovú kategóriu 35 - 54 rokov. Obsah tejto reklamy by mal byt' pravdivý a nemal by obsahovat' prvky násilia a vulgárností. Dôležité je aby bola na túto vekovú kategóriu cielená reklama tak, aby nemali pocit že ich daná reklama manipuluje a zavádza. 


\section{Literatúra}

[1] ČOREJOVÁ, T., ROSTÁŠOVÁ, M., CHRENKOVÁ, A.: Market planning in the market economy, In: Visnyk Chmel'nyckoho nacional'noho universytetu : naukovyj žurnal. Ekonomični nauky Tom 2. - 4 (2010), s. 29-32.

[2] ČOREJOVÁ, T.: Rozvoj informačno-komunikačnej infraštruktúry v regiónoch SR, In: Hradecké ekonomické dny 2008: Strategie rozvoje regionů a států : Hradec Králové 5. a 6. února 2008. - Hradec Králové : Gaudeamus, 2008. - ISBN 978-80-7041-202-2.

[3] ŠVEC, M.: Dopad hospodárskej krízy na akceptáciu internetovej reklamy zákazníkmi, diplomová práca, Katedra spojov, ŽU Žilina, 2010

[4] KREMEŇOVÁ, I., FABUŠ, J.: Aplikácie marketingových informačných systémov v podnikoch, In: MARVI Marketing vzdelávacích inštitúcií : 2. ročník medzinárodnej vedeckej konferencie: Žilina 21. a 22. október 2010 : zborník prednášok a príspevkov. Žilina : Žilinská univerzita, 2010. - ISBN 978-80-554-0262-8. - S. 90-93. -

[5] MADLEŇÁKOVÁ, L., MAJERČÁKOVÁ, M: Legislatíva $\mathrm{v}$ poštových službách a elektronických komunikáciách - 1. vyd. - Žilina : Žilinská univerzita v Žilina, 2007. ISBN 978-80-8070-789-7.

[6] MADLEŇÁKOVÁ, L.: Hodnotenie postavenia telekomunikačných operátorov, In: Doprava a spoje: internetový časopis. - ISSN 1336-7676. - Č. 1 (2007), 8 s

[7] ŠTOFKOVÁ, J.: Manažment podniku, EDIS vydavatel'stvo ŽU, Žilina, 2007, ISBN 978 8070-713-2

[8] VACULÍK, J.: História a vývojové trendy v oblasti elektronických komunikácií, In: Pošta, Telekomunikácie a Elektronický obchod - ISSN 1336-8281. - Roč. 5, č. 3 (2010), s. 35-39.

\section{Grantová podpora}

- AV 4/2045/08 Aplikácie technológie RFID pre vybrané poštové procesy na podmienky HSS

- VEGA 1/0149/10 Difúzne procesy nových mobilných služieb a ich hodnotový ret'azec

- VEGA 1/0760/10 Využitie strategického manažmentu pre podporu rozvoja regiónu

- KEGA - 036-017ŽU-4/2010 Data modeling v procese vzdelávania v počítačovom laboratóriu Katedry spojov 